\title{
A NEW SPECIES OF STENOBOTHRUS FROM CONNECTICUT, WITH REMARKS ON OTHER NEW ENGLAND SPECIES.
}

\author{
BY A. P. MORSE, WELLESLEY, MASS.
}

Stenobothrus olivaceus, sp. nov. Closely approaching $S$. maculipennis Scudd. Head conical. Face very oblique. Vertex nearly horizontal; acute at apex, in the $\delta$ more, in the $q$ less, the sides slightly excavate; narrow between the eyes, in the $q$ about equal to the width of an eye, in $\delta$ less; slightly expanded at anterior margin of eyes. Central foveola of vertex rather deep; its edges broad, raised; its depression slightly $(\delta)$ or distinctly ( $q$ ) in advance of eyes, removed from the tip of vertex about two-thirds $(\delta)$ or onehalf $(q)$ the distance between eyes. [See fig.] Facial costa shallowly sulcate, more deeply so than in maculipennis, the margins sharp; at meeting with the vertex angulate, not rounded as in maculipennis. Lateral foveolae distinct. Eyes slightly smaller and less prominent than in maculipennis; seen from the side the upper front portion is more angulate in $\$$, more rounded in $\delta$ than in maculipennis. Antennae rather short, variable, about equal to head and prothorax; slightly flattened toward the base, at tip gradually tapering to a fine point. Thorax rather stout. Pronotum with the median carina distinct, sharp. Lateral carinae distinct; on the anterior half of prozona subparallel or slightly convergent, on the remaining portion of pronotum evenly divergent. Their course is straighter, less made up of curves, and less convergent on the prozona than in maculipennis. Tegmina long, passing hind femora by one-eighth to one-sixth their length. Wings longer and more pointed than in maculipennis. Hind femora long, passing tip of abdomen, and rather slender.

Color. In general either olivaceous-brown or light green above, paler brown below; with the usual dark longitudinal band along lateral carinae of pronotum and middle of tegmina less sharply defined and in the male becoming obsolete. The colors are dead and have a faded appearance, with a peculiar olivaceous tinge matching the tints of the vegetation of its haunts. The dusky bands of the tegmina are less distinct in brown than in green specimens, and in males than in females. Brown specimens are the more plentiful.

Green specimen, fresh. Face and cheeks pale pea-green. Eyes brown or slate, considerably darker than surroundings. Clypeus, labrum and mouthparts light brown, palpi paler or white. A brown or fuscous band running backward from upper half of each eye over occiput. Antennae light brown at base, darker toward tip. Pronotum pale peagreen; the sides with a dark band running along the dorsal third, black nearest carinae, crossing them upon the disk of metazona. Lateral carinae pale green or whitish.

Meso- and meta thorax with the sides pale green. Pectus light brown. Tegmina pale green; opaque, becoming translucent on apical half; a dark median band. composed of nearly confluent small dusky spots extending usually one-third, rarely two-thirds, its length, the edges indistirct; this band is narrower and shorter than in maculipennis, the spots smaller and less distinct. Wings transparent, veins and venules dusky; preapical fourth of costal margin opaque greenish, the veins heavily infuscated. Femora green or brownish, tibiae and tarsi light brown; spines of hind tibiate tipped with black.

Abdomen with the dorsum brown, lightest at sides and on narrow median line, bordered below by a broad griseous or fuscous band punctate with black; pleurae palest, light brown; venter light brown; ovipositor brown, black at extreme tip.

Brown specimens vary from pale brownish 
straw to a rather dark olive-brown above, lighter and of a more olivaceous cast below. The occiput generally shows the usual two dusky longitudinal lines. Sides of pronotum varied in middle third with dusky brown and pale griseous, the ventral third light gray or white. Episterna of metathorax with pale oblique bands running downward toward fossa 3. Hind femora brown above and below ; tibial groove greenish; disk pale gray or nearly white on proximal half. its midline often dusky interrupted with pale, forming two sub-distinct dusky spots on proximal two fifths of femora, which are indistinct in dry specimens; inner side similar to outer except that the ground-color is paler and the spots darker.

Measurements. Antenna: $\delta, 6-7 \mathrm{~mm}$;

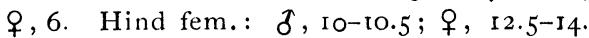
Teg.: $\delta$, I $^{-1} 5$; + I $7-2 \mathrm{I}$. Body: $\delta$, I6.5-18.7;,$+ 21-25$. Total length: $\delta$, I9-20.7;,$+ 23.5^{-28}$.

I80 $\delta, 167 \%$.* Greeuwich and Stamford, Conn., Aug. 1ith to 28th.

This species though not widely spread was locally very plentiful in the salt marshes, its green and olivaceous tints closely matching in color the marsh grasses in which it made its home. The ground beneath was often overtlowed at high tide and offered a retreat

* Owing to the large number of types on hand specimens will be sent, for the accommodation of other students of the family, to a number of collections in various parts of the country, as follows:-

Museum of Comparative Zoology, Cambridge, Mass. Mr. S. H. Scudder, Cambridge, Mass.

Mr. Samuel Henshaw, Cambridge, Mass.

Massachusetts Agricultural College, Amherst, Mass.

American Museum of Natural History, New York. Cornell University, Ithaca, N. Y.

American Entomological Society, Philadelphia, Pa. National Museum, Washington, D. C.

Mr. W. S. Blatchley, Terre Haute, Ind.

State Experiment Station, St. Anthony Park, Minn. University of Nebraska, Lincoln, Neb.

Prof. Lawrence Bruner, Lincoln, Neb.

Leland Stanford, Jr., University, Palo Alto, Cal.

Entomological Society of Ontario, London, Canada. National Museum, Ottawa, Canada. to myriads of fiddler-crabs, being much wetter and of a wholly different character from the situations frequented by maculipennis and aequalis.

As has been stated this species closely approaches maculipennis. Some of the brown females bear a superficial resemblance to long-winged specimens of curtipennis, but the antennae and head readily distinguish them therefrom.
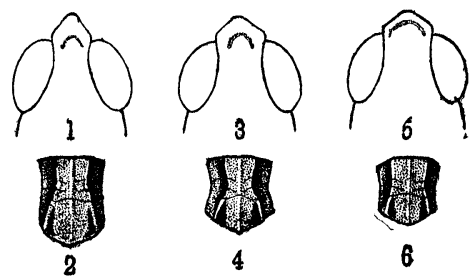

Fig. I, S. olivaceus, ठ. Fig. 2, S. olivaceus, \&. Fig. 3, S. maculipennis, $\delta$. Fig. 4, S. maculipennis, ㅇ. Fig. 5, S. aequalis, ठ. Fig. 6, S. aequalis, + . Figs. 2, 4, 6, $\times 2$ diameters.

Compared with maculipennis, the vertex is more nearly horizontal, more acute, more angulate with the front in profile; more narrowed between the eyes; the depression of the central foveola further removed from the apex. The face is more oblique; the antennae are shorter, more flattened toward base, and more finely pointed. The disk of the prozona is broader, its sides less incurved, their outlines formed by straight lines rather than curves, and the metazona very nearly as long as the prozona.

From aequalis also it is readily distinguished by the characters of the head and vertex mentioned above, while the disk of the pronotum is proportionally much more narrowed anteriorly and the metazona much longer.

In sorting these species I have found it easier, owing to their larger size, to separate the females first.

It seems best to make a few statements 
here concerning the other two species referred to,- $S$. maculipennis Scudd. and $S$. aequalis Scudd. From my collections gathered during the last three seasons and notes concerning them taken in the field, I am fully convinced of the distinctness of these species.

S. aequalis I have found one of the most plentiful locusts in New England, everywhere common on dry soil, and very variously colored. With this species I unite $S$. bilineatus Scudd.

$S$. maculipennis on the other hand I have taken only in Southern New England, where I have found it most plentiful near the coast, preferring sandy soils. This species also is very variously colored. Individuals of both species may be wholly either brown or green or any mixture of the two, but green males are the least common of any of the forms and $i_{n}$ some places are exceedingly scarce. Not infrequently specimens show considerable rose-red above or may be very largely blackish-fuscous throughout.

The structural characters presented by the head, vertex, and pronotum are the best means of separating these species from each other and from olivaceus, but the length and markings of the tegmina are also helpful.

It may be of interest in this connection to state that I have examined some of the specimens collected by Prof. S. I. Smith at Norway, Me., and referred to in his paper on the Orthoptera of Maine as $S$. maculipennis, and also some in the collection of Cornell University collected in New York and referred to in Prof. Comstock's Introduction to Entomology under the same name. All of these I am disposed to consider as belonging to aequalis. Some of the Norway, Me., specimens show an unusual length of wing but assuredly are not maculipennis Scudd. I have also examined the types in Mr. Scudder's collection.

\section{ADDITIONS TO THE LIST OF BOMBYCES AT POUGHKEEPSIE.}

BY HARRISON G. DYAR, BOSTON, MASS.

In the August, I89I, number of Psyche I gave a list of the Bombyces found in Poughkeepsie, N. Y., and included four species of Arctia. Further study has shown that this list must be increased to seven species. From my series of $A$. virgo I have picked out two specimens which are referable to $A$. intermedia Str. They are of the form in which the markings of the fore wings are practically as in $A$. virgo, being less extensive than in Stretch's figure. This form differs from $A$. parthenice Kirby only in size, and may prove to be a southern race of it. Parthenice occurs not rarely at Plattsburgh, N. Y.; but I have never met with it in Dutchess County. The $\delta$ genitalia of these forms do not differ specifically. I have made drawings from balsam mounts and cannot find any differences which are greater than the range of individual variation. From the same parts in $A$. virgo they differ slightly and probably to a degree which is specific.

Under the term nais in my list were included all the forms with the pattern of marking of that species. I am now satisfied that we have not two species, nais and decorata, as they stand in Professor Smith's list, but three well defined and distinct species, differing in markings of the moth, in the larva according to the observations of Prof. G. H. French and Mr. J. Doll, and in the structure of the $\delta$ genitalia. In another 

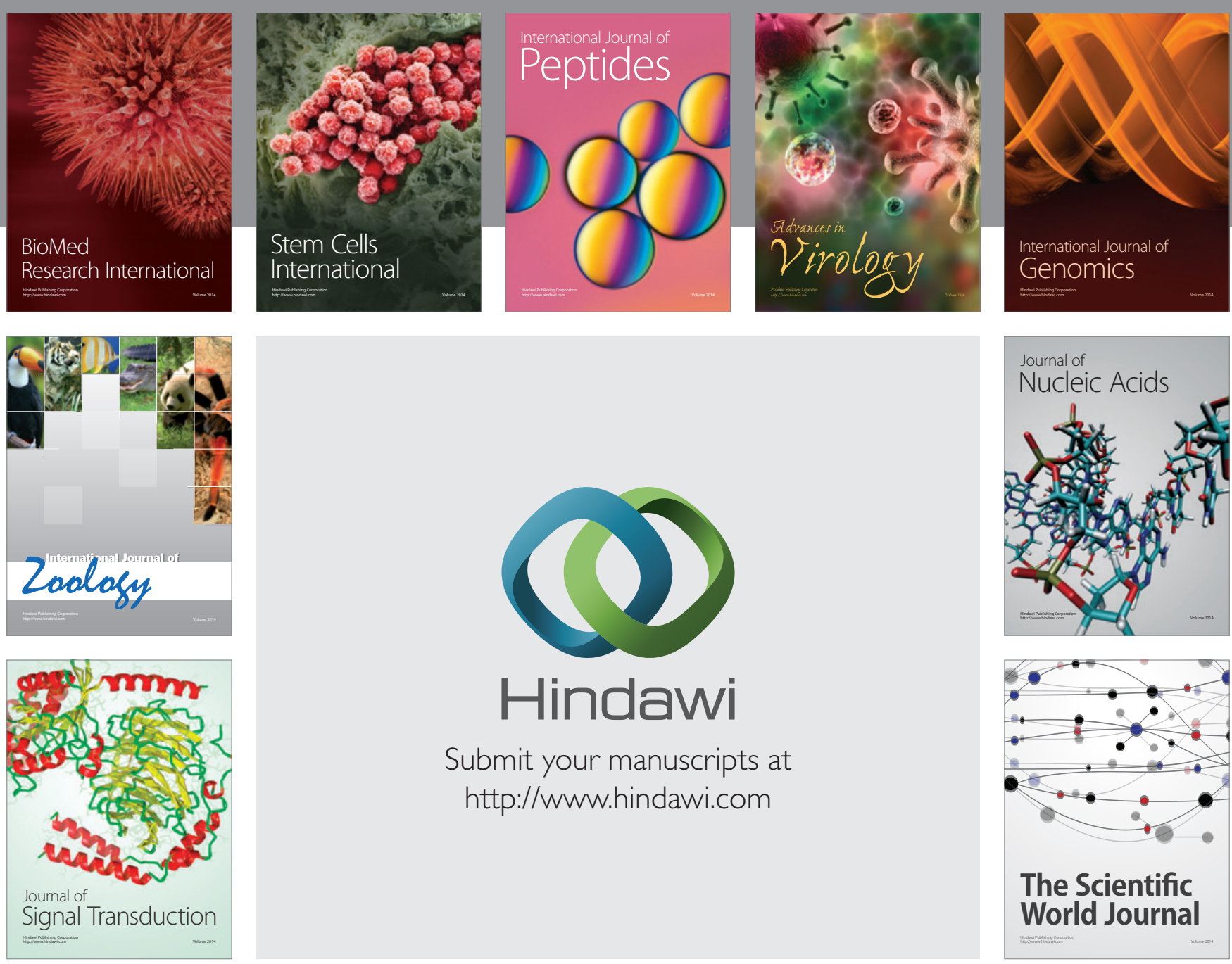

Submit your manuscripts at

http://www.hindawi.com
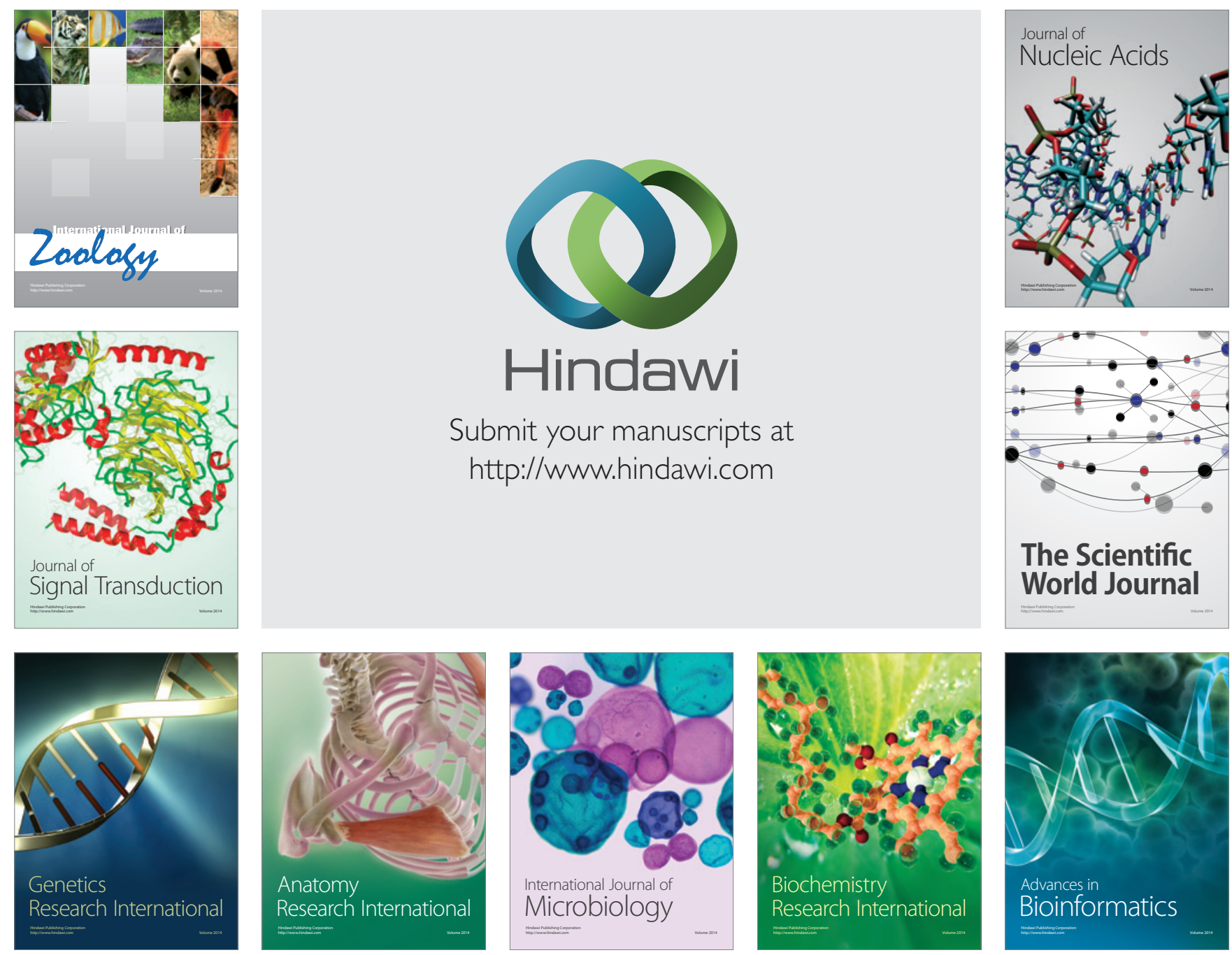

The Scientific World Journal
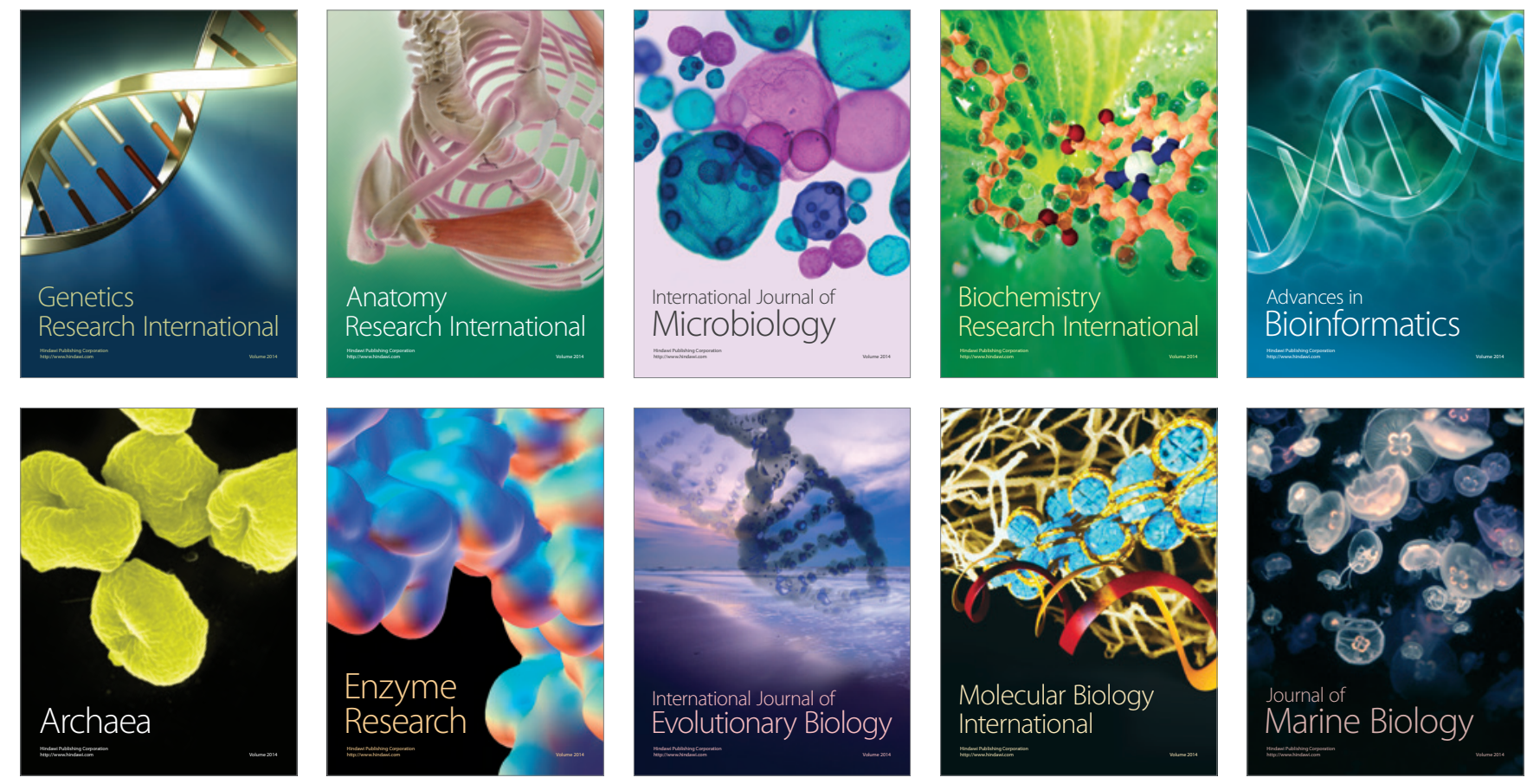